Jurnal Manajemen dan Kewirausahaan, Volume 9, Nomor 3, September 2018

ISSN: $2086-5031$

E-ISSN 2615-3300

DOI 10.31317

\title{
Peran Sektor Pertanian Terhadap Perekonomian Indonesia (Analisis Input-Output)
}

\author{
Oleh: \\ Heppi Syofya, Silvia Rahayu \\ STIE Sakti Alam Kerinci \\ hsyofya@gmail.com, silviarhy1038@gmail.com
}

\begin{abstract}
The strategic role of the agricultural sector in the national development includes: providing food for the Indonesian population, foreign exchange earners through exports, supplying industrial raw materials, increasing employment and business opportunities, increasing regional income, alleviating poverty and driving the movement of other economic sectors. In fact, until now the agricultural sector still faces many problems. Government policies that are not in favor of the agricultural sector are obstacles to the development of the agricultural sector. The government is more concerned with the industrial sector because the industry sector has been claimed to provide high income compared to the agricultural sector. Investors are also more interested in investing in the industrial sector than in the agricultural sector. The purpose of this study is to see the magnitude of the relationship between agricultural sub-sectors, both in the future and backward, in the Indonesian economy, seeing the magnitude of the influence of the agricultural sector on the increase in total output, community income, and absorption of Indonesian labor, and see what agricultural sub-sectors can be classified as a leading commodity, potential and lagging commodity in Indonesia based on the ranking of the forward and backward linkages, the agricultural sub-sector that can be classified as a sector that triggers economic growth, the income generating sector and the labor absorption sector based on the number multiplier.
\end{abstract}

Keywords : Agricultural sector commodity, input-output.

\section{A. PENDAHULUAN}

Salah satu tujuan pembangunan ekonomi adalah mewujudkan masyarakat yang dapat menikmati keadilan dan kemakmuran yang dirasakan oleh seluruh lapisan masyarakat yang sesuai dengan kapasitas dan kemampuan ekonomi yang dimiliki suatu daerah dalam menghasilkan barang dan jasa yang diperlukan bagi kebutuhan hidup masyarakat. Oleh karena itu pembangunan di bidang ekonomi merupakan persoalan yang sangat penting untuk meningkatkan kualitas hidup masyarakat. Peningkatan kualitas hidup masyarakat salah satunya dapat dilihat dari sektor pertanian. Pentingnya peranan sektor

Program Studi Manajemen Fakultas Ekonomi Universitas Tamansiswa Padang 
Jurnal Manajemen dan Kewirausahaan, Volume 9, Nomor 3, September 2018

ISSN: $2086-5031$

E-ISSN 2615-3300

DOI 10.31317

pertanian menjadi salah satu komponen pembangunan nasional dalam menuju swasembada pangan guna mengentaskan kemiskinan. Pertanian sudah menjadi way of life bagi sebagian besar masyarakat Indonesia. Wajah pertanian akan kembali cerah manakala para pelaku dengan didukung oleh pemerintah dapat memahami peran dan fungsi pertanian, serta mampu mengelolanya dengan benar sesuai dengan perkembangan kebutuhan manusia. Sektor pertanian hingga kini masih memiliki peranan yang starategis dalam pembangunan nasional, baik bagi pertumbuhan ekonomi maupun pemerataan pembangunan. Peran strategis sektor pertanian dalam pembangunan nasioanl antara lain : penyedia pangan bagi penduduk Indonesia, penghasil devisa negara melalui ekspor, penyedia bahan baku industri, peningkatan kesempatan kerja dan usaha, peningkatan pendapatan daerah, pengentasan kemiskinan dan pendorong bergeraknya sektor-sektor ekonomi lainnya. Pada kenyatannya, sampai saat ini sektor pertanian masih menghadapi banyak permasalahan. Kebijakan pemerintah yang kurang berpihak pada sektor pertanian menjadi kendala dalam perkembangan sektor pertanian. Pemerintah lebih memperhatikan sektor industri karena sektor industri selama ini diklaim memberikan pendapatan yang tinggi dibandingkan dengan sektor pertanian. Investor juga lebih tertarik menanamkan modalnya pada sektor industri dibandingkan sektor pertanian. Tujuan penelitian ini adalah melihat besarnya keterkaitan antar sub-sektor pertanian, baik kedepan maupun kebelakang, dalam perekonomian Indonesia, melihat besarnya pengaruh sektor pertanian terhadap kenaikan total output, pendapatan masyarakat, dan penyerapan tenaga kerja Indonesia, dan melihat Sub-sektor pertanian apa saja yang dapat digolongkan sebagai komoditi unggulan, potensial dan komoditi tertinggal di Indonesia berdasarkan peringkat kaitan kedepan dan kebelakangnya, sub-sektor pertanian yang dapat digolongkan sebagai sektor pemicu pertumbuhan ekonomi, sektor pemacu pendapatan dan sektor penyerapan tenaga kerja berdasakan perolehan angka pengganda.

\section{B. METODE PENELITIAN}

\section{Rancangan Penelitian}

Rancangan penelitian dalam permasalahan ini adalah dengan menggunakan metode penelitian deskriptif

Program Studi Manajemen Fakultas Ekonomi Universitas Tamansiswa Padang 
Jurnal Manajemen dan Kewirausahaan, Volume 9, Nomor 3, September 2018

ISSN: $2086-5031$

E-ISSN 2615-3300

DOI 10.31317

yaitu gambaran mengenai sasaran.

Dalam melakukan penelitian ini, Maksudnya adalah penulis ingin menerangkan bagaimana peran sektor pertanian terhadap Indonesia, terutama keterkaitan antara sektor pertanian dengan sektor-sektor ekonomi lainnya termasuk dengan sektor pertanian itu sendiri (Backward Linkage dan Forward Linkage) maupun peranan sektor pertanian dalam meningkatkan pendapatan masyarakat dan penyerapan tenaga kerja di Indonesia.

\section{Jenis dan Sumber Data}

Jenis data yang digunakan dalam penelitian ini adalah data sekunder yaitu data Tabel Input-Output Indonesia Tahun 2015 dengan matriks 185 x 185 dengan 17 (tujuh belas) pembagian komoditi sektor pertanian Indonesia. Dalam penelitian ini banyak sektor yang digunakan adalah semua sektor yang berhubungan dengan pertanian, sektor tersebut terdapat pada tabel InputOutput Indonesia. Sumber data dalam penelitian ini diperoleh dari Badan Pusat Statistik (BPS), Departemen Departemen Pertanian, serta berbagai literatur yang berkaitan dengan tujuan penelitian antara lain majalah, buku, jurnal, hasil penelitian terhadulu, internet, serta studi pustaka.

Metode Pengumpulan Data Secara khusus, model Harrod-Domar

Program Studi Manajemen Fakultas Ekonomi Universitas Tamansiswa Padang 
Jurnal Manajemen dan Kewirausahaan, Volume 9, Nomor 3, September 2018

ISSN: $2086-5031$

E-ISSN 2615-3300

DOI 10.31317

berpendapat bahwa tingkat pertumbuhan

Output $(\Delta \mathrm{Y} / \mathrm{Y})$ berhubungan secara positif dengan rasio tabungan, namun berhubungan negative dengan capital-output ratio (COR) (Arsyad, 2015). Dengan kata lain, pertumbuhan ekonomi ditentukan oleh rasio modal-output $(\mathrm{COR}=\mathrm{k})$, atau $: \underline{\Delta \mathrm{Y}}=\underline{\mathrm{s}}$.

$$
Y \quad k
$$

ICOR merupakan kebalikan dari COR yang menunjukkan seberapa jauh output akan berubah akibat adanya modal. diatas menunjukkan bagaimana aplikasi modal Input-Output dan Harrod-Domar dalam menentukan tingkat kebutuhan investasi sektoral. Dari model Input-Output dapat diketahui bagaimana pengaruh perubahan permintaan akhir terhadap pertumbuhan output untuk masing-masing sektor. Bila data ICOR diperoleh, maka kita dapat menghitung besarnya kebutuhan investasi untuk masing-masing sektor (Kuncoro, 2004).

\section{Metode Analisis Data}

Dalam rangka mencapai tujuan yang telah di rumuskan serta menjawab permasalahan dalam penelitian ini, maka penulis menggunakan data Tabel InputOutput Indonesia Tahun 2015. Metode analisis yang akan digunakan oleh penulis adalah deskriptif kuantitatif, yaitu membahas dan menganalisa data table Input-Output yang telah ada, untuk melihat dampak nilai tambah sektor pertanian dilihat dari indeks keterkaitan (backward linkage dan forward linkage), angka pengganda (pengganda output, pengganda pendapatan masyarakat dan pengganda penyerapan tenaga kerja) di Indonesia. Analisa keterkaitan antar sektor digunakan sebagai dasar perumusan strategi pembangunan ekonomi dengan melihat keterkaitan antar sektor dalam suatu sistem perekonomian.

\section{Indeks Keterkaitan ke Belakang (Backward Linkage Indeks)}

Konsep ini diartikan sebagai
kemampuan suatu sektor untuk
meningkatkan pertumbuhan sektor hulunya.
Sektor j dikatakan mempunyai kaitan ke
belakang yang tinggi apabila $B L_{j}$
mempunyai nilai lebih besar dari satu.
Rumus yang digunakan untuk mencari nilai
indeks total keterkaitan ke belakang adalah :


Jurnal Manajemen dan Kewirausahaan, Volume 9, Nomor 3, September 2018

ISSN: $2086-5031$

E-ISSN 2615-3300

DOI 10.31317

$$
B L_{j}=\frac{n \sum_{i=1}^{n} \alpha_{i j}}{\sum_{i=1}^{n} \sum_{j=1}^{n} \alpha_{i j}} \quad \begin{aligned}
& \text { Dimana: } \\
& B L_{j}=\text { indeks keterkaitan ke belakang sektor } \mathrm{j} \\
& \alpha_{i j}=\text { unsur matriks kebalikan Leontief }
\end{aligned}
$$

2. Indeks Total Keterkaitan ke Depan (Forward Linkage Indeks)

Konsep ini diartikan sebagai kemampuan suatu sektor untuk mendorong pertumbuhan produksi sektor-sektor lain yang memakai input dari sektor ini. Sektor i dikatakan mempunyai indeks total keterkaitan ke depan yang tinggi apabila nilai $F L_{i}$ lebih besar dari satu. Rumus yang digunakan untuk mencari nilai indeks total keterkaitan ke depan adalah :

$$
F L_{i}=\frac{n \sum_{j=1}^{n} \alpha_{i j}}{\sum_{i=1}^{n} \sum_{j=1}^{n} \alpha_{i j}} \quad \begin{aligned}
& \text { Dimana: } \\
& \alpha_{i}=\text { Indeks total keterkaitan ke depan sektor i }
\end{aligned}
$$

Matriks pengganda dari suatu Table Input-Output merupakan kerangka dasar untuk berbagai analisis ekonomi dan pengembangan model Input-Output lebih lanjut.

\section{Indeks Pendapatan Masyarakat (Income Multiplier Indeks)}

Indeks pendapatan masyarakat total pendapatan masyarakat untuk setiap kenaikan satu satuan output yang dihasilkan suatu sektor. Sebuah sektor dikatakan mempunyai peran yang tinggi dalam menarik pendapatan masyarakat jika indeks pendapatan masyarakat lebih besar dari satu. Rumus yang digunakan untuk mencari nilai indeks pendapatan masyarakat adalah :

digunakan untuk melihat besarnya kenaikan

$$
H_{j}=\frac{n \sum_{i=1}^{n} \frac{v_{i}}{X_{i}} \alpha_{i j}}{\sum_{i=1}^{n} \sum_{j=1}^{n} \frac{v_{i}}{X_{i}} \alpha_{i j}} \quad \begin{aligned}
& \text { Dimana: } \\
& H_{j}=\text { Indeks pendapatan masyarakat sektor } \mathrm{j} \\
& v_{i}=\text { upah/gaji sektor } \mathrm{i}
\end{aligned}
$$


Jurnal Manajemen dan Kewirausahaan, Volume 9, Nomor 3, September 2018

ISSN: $2086-5031$

E-ISSN 2615-3300

DOI 10.31317

\section{Indeks Tenaga Kerja (Employment Multiplier Indeks)}

Untuk mencari nilai indeks tenaga kerja perlu ditambahkan baris baru pada tabel I-O yang memuat informasi tenaga kerja yang digunakan oleh masing-masing sektor dalam melakukan proses produksinya. Umumnya, satuan jumlah tenaga kerja sektoral yang digunakan adalah orang. Jumlah tenaga kerja per satuan output untuk sektor $\mathrm{i}$ ditulis $w_{i}$.Analisis indeks tenaga kerja ini digunakan untuk melihat peran suatu sektor dalam hal meningkatkan besarnya jumlah tenaga kerja yang diserap oleh perekonomian. Jika indeks tenaga kerja di suatu sektor lebih besar dari satu menunjukkan daya serap tenaga kerja di sektor yang bersangkutan sangat tinggi. Rumus yang digunakan untuk mencari nilai indeks tenaga kerja adalah :

$$
L_{j}=\frac{n \sum_{i=1}^{n} w_{i} \alpha_{i j}}{\sum_{i=1}^{n} \sum_{j=1}^{n} w_{i} \alpha_{i j}} \quad \begin{aligned}
& \text { Dimana: } \\
& L_{j}=\text { Indeks tenaga kerja sektor } \mathrm{j} \\
& \alpha_{i j}=\text { unsur mastriks kebalikan Leontief } \\
& X_{i}=\text { output sektor } \mathrm{i} \\
& \alpha_{i j}=\text { unsur mastriks kebalikan Leontief }
\end{aligned}
$$

\section{HASIL DAN PEMBAHASAN}

1. Analisis Indeks Keterkaitan Kebelakang (Backward Linkage Indeks)

Setelah dilakukan perhitungan nilai indeks kebelakang atau backward linkage indeks, hasil perhitungan untuk ke 17 (tujuh belas) komoditi sektor pertanian Indonesia dirangking berdasarkan nilai tertinggi adalah sebagai berikut : (001). Komoditi Padi dengan nilai perhitungan sebesar 8,919268,
(010). Komoditi Sayuran sebesar 2,339875, (003). Komoditi Jagung sebesar 2,261537, (016). Komoditi Buah-buahan sebesar 0,848595, (004). Komoditi ubi Jalar sebesar 0,76651, (007). Komoditi Kedelai sebsar 0,533366, (012). Komoditi Tebu sebesar 0,522025, (006). Komoditi Kacang Tanah Sebesar 0,336775, (003). Komoditi Ubi Jalar sebesar 0,260209. Pada gambar 1. berikut ini dapat dilihat 5 (lima) komoditi yang menjadi unggulan di Indonesia. 


\section{Gambar 1.}

Nilai Indeks Keterkaitan Kebelakang (Backward Linkage Indeks) Sektor Pertanian Indonesia

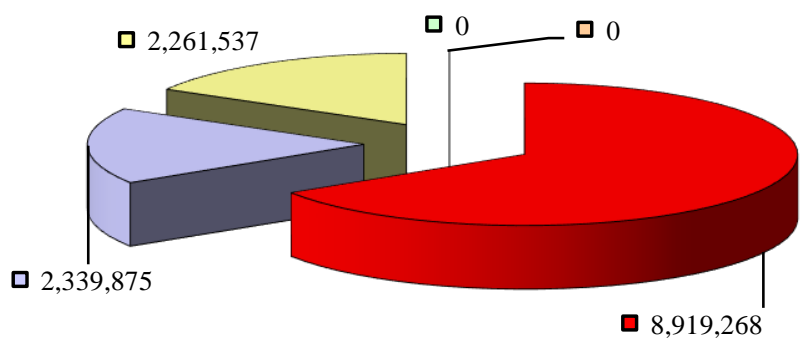

口Komoditi Padi

口Komoditi Sayuran

口Komoditi Jagung

$\square$ Komoditi Buah-buahan

口Komoditi Ubi Jalar

Sumber : Data diolah, 2018.

Komoditi sektor pertanian Indonesia lainnya adalah: (008). Komoditi Kacangkacangan Lainnya sebesar 0,104537, (005). Komoditi Umbi-umbian lainnya sebesar 0,052428, (011). Komoditi Tanaman Hias sebesar 0,028566, (017). Komoditi Tanaman Biofarma sebesar 0,01079, (013). Komoditi Tembakau sebesar 0,007183, (014). Komoditi Tanaman Serat sebesar 0,003406, (015). Komoditi Hasil Perkebunan Lainnya sebesar 0,002737 dan (009). Komoditi Padipadian dan bahan makanan lainnya sebesar 0,002055. Dimana komoditi ini memiliki peran aktif dalam peningkatan pendapatan masyarakat, selain itu komoditi ini juga sangat berperan aktif dalam peningkatan produktivitas tenaga kerja, yang pada umumnya bergerak pada sektor pertanian.
Sektor pertanian masih memiliki peran penting dalam mendorong pertumbuhan ekonomi Indonesia sampai saat ini, selain itu juga sektor pertanian menjadi pemacu pergerakan sektor industri khususnya sektor pertanianan bahan makanan dan hasil pertanian. Nilai komoditi sektor pertanian adalah sebesar 17, artinya : bahwa setiap satu persen kenaikan permintaan akhir sektor pertanian ini akan mendorong peningkatan output pada sektor-sektor yang digunakan sebagai input oleh ke 17 (tujuh belas) komoditi yang ada pada sektor pertanian. Rendahnya nilai indeks sektor pertanian disebabkan karena tidak banyak menggunakan input dari komoditi sektor lainnya. Hal inilah yang membuat komoditikomoditi sektor pertanian memiliki nilai

Program Studi Manajemen Fakultas Ekonomi Universitas Tamansiswa Padang 
Jurnal Manajemen dan Kewirausahaan, Volume 9, Nomor 3, September 2018

ISSN: $2086-5031$

E-ISSN 2615-3300

DOI 10.31317

rendah dibandingkan komoditi sektor ekonomi Indonesia.

2. Analisis Indeks Keterkaitan Kedepan (Forward Linkage Indeks)

Dari hasil perhitungan indeks keterkaitan kedepan, dilakukan tahap analisis keterkaitan ke depan yaitu analisis keterkaitan kedepan menurut komoditi sektor. Hasil perhitungan indeks keterkaitan kedepan berdasarkan komoditi-komoditi sektor pertanian Indonesia dengan nilai 5 (lima) terbesar dibandingkan komoditi lainnya adalah : (001). Komoditi Padi sebesar 8,919268, (002). Komoditi Jagung sebesar 2,261537, (010). Komoditi Sayursayuran sebesar 1,648566, (016). Komoditi Buah-buahan dengan nilai sebesar 1,539903, dan (004). Komoditi Ubi Kayu dengan nilai sebesar 1,539903.

\section{Gambar 2.}

Nilai Indeks Keterkaitan Kedepan (Forward Linkage Indeks) Sektor Pertanian Indonesia

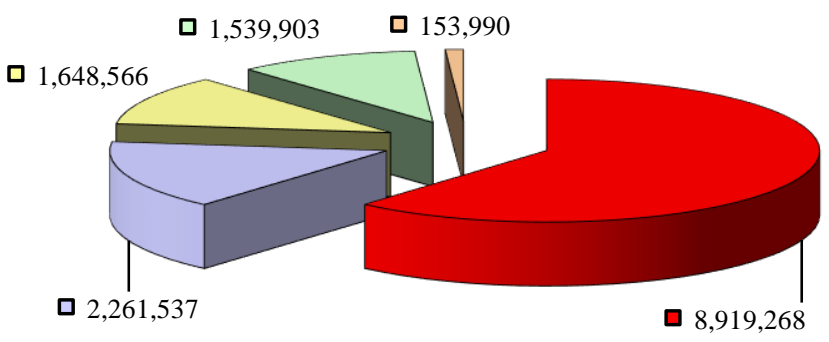

Sumber : Data diolah, 2018.

Komoditi sektor pertanian Indonesia lainnya adalah (007). Komoditi Kedelai dengan nilai sebesar 0,53366, (012). Komoditi Tebu sebesar 0,5220250, (006). Komoditi Kacang tanah sebesar 0,336775, (003). Komoditi Ubi Jalar sebesar 0,260209, (008). Komoditi Kacang-kacang lainnya sebesar 0,104535, (011). Komoditi Tanaman
Hias sebesar 0,028566, (017). Komoditi Tanaman Biofarma sebesar 0,01079, (013). Komoditi Tembakau sebesar 0,007183, (005). Komoditi Umbi-umbian sebesar 0,00405, (014). Komoditi Tanaman Serat sebesar 0,003406, (015). Komoditi Hasil Perkebunan Lainnya sebesar 0,002737, dan (017). Komoditi Tanaman Biofarma sebesar

Program Studi Manajemen Fakultas Ekonomi Universitas Tamansiswa Padang 
Jurnal Manajemen dan Kewirausahaan, Volume 9, Nomor 3, September 2018

ISSN: $2086-5031$

E-ISSN 2615-3300

DOI 10.31317

0,002055. Nilai sektor pertanian Indonesia berdasarkan perhitungan adalah sebesar 17 dengan artian bahwa setiap satu persen penggunaan input dari sektor pertanian oleh sektor lainnya akan menyebabkan peningkatan output terhadap sektor lain yang menggunakan sektor pertanian sebagai input sebesar 17 persen.

Berdasarkan hasil analisis indeks keterkaitan kebelakang (backward linkage indeks) dan keterkaitan kedepan (forward linkage indeks) secara komoditi, maka sektor perekonomian dapat dikelompokkan menjadi 3 (tiga) kelompok, yaitu: kelompok komoditi unggulan, komoditi potensial, dan komoditi tertinggal. Komoditi unggulan adalah komoditi yang memiliki nilai indeks keterkaitan kebelakang tinggi dan indeks keterkaitan kedepan tinggi. Komoditi yang termasuk dalam kategori potensial adalah komoditi yang memiliki nilai indeks keterkaitan kebelakang tinggi dan indeks keterkaitan kedepan rendah, bahkan sebaliknya. Sedangkan komoditi yang masuk dalam komoditi tertinggal adalah komoditi yang nilai indeks keterkaitan kebelakang dan kedepannya rendah.

Tabel 1

Hubungan Antara Kaitan ke Belakang dan Kedepan Komoditi-Komoditi Sektor Pertanian Indonesia

\begin{tabular}{|c|c|c|c|}
\hline & \multicolumn{2}{|c|}{ Kaitan Ke Belakang } \\
\hline & & Tinggi & Rendah \\
\hline $\begin{array}{c}\mathbf{K} \\
\mathbf{a} \\
\mathbf{i} \\
\mathbf{t} \\
\text { an }\end{array}$ & $\begin{array}{l}\mathrm{T} \\
\mathrm{i} \\
\mathrm{n} \\
\mathrm{g} \\
\mathrm{g} \\
\mathrm{i}\end{array}$ & $\begin{array}{l}\text { (001). Komoditi Padi } \\
\text { (002). Komoditi Jagung } \\
\text { (010). Komoditi Sayur-sayuran }\end{array}$ & (016). Komoditi Buah-buahan \\
\hline $\begin{array}{c}\text { ke } \\
\text { De } \\
\text { pa } \\
\text { n }\end{array}$ & $\begin{array}{l}\mathrm{R} \\
\mathrm{e} \\
\mathrm{n} \\
\mathrm{d} \\
\mathrm{a} \\
\mathrm{h}\end{array}$ & (016). Komoditi Buah-buahan & $\begin{array}{l}\text { (004). Komoditi Ubi Kayu } \\
\text { (007). Komoditi Kedelai } \\
\text { (012). Komoditi Tebu } \\
\text { (006). Komoditi Kacang Tanah } \\
\text { (003). Komoditi Ubi Jalar } \\
\text { (008). Komoditi Kacang-kacangan } \\
\text { Lainnya } \\
\text { (011). Komoditi Tanaman Hias } \\
\text { (017). Komoditi Tanaman Biofarma } \\
\text { (013). Komoditi Tembakau } \\
\text { (014). Komoditi Tanaman Serat } \\
\text { (015). Komoditi Hasil Tanaman Perkebunan Lainya } \\
\text { (009). Komoditi Padi-padian dan bahan makanan } \\
\text { Lainnya }\end{array}$ \\
\hline
\end{tabular}

Sumber : Data diolah dari Tabel Input-Output Indonesia.

Program Studi Manajemen Fakultas Ekonomi Universitas Tamansiswa Padang 
Jurnal Manajemen dan Kewirausahaan, Volume 9, Nomor 3, September 2018

ISSN: $2086-5031$

E-ISSN 2615-3300

DOI 10.31317

Tabel diatas menggambarkan perekonomian sektor pertanian Indonesia yang dikategorikan sebagai komoditi unggulan, komoditi potensial dan komoditi tertinggal. Komoditi unggulan sektor pertanian Indonesia adalah (001). Komoditi padi, (002). Komoditi jagung dan (010). Komoditi sayur-sayuran, komoditi tergolong potensial pada sektor pertanian adalah (016). Komoditi Buah-buahan, sedangkan 12 (dua belas) komoditi lainnya adalah komoditi dengan kategori tertinggal pada sektor pertanian Indonesia. Dari hasil analisis dapat dikatakan bahwa (004). Komoditi Ubi Kayu, (007). Komoditi Kedelai, (012). Komoditi Tebu, (006). Komoditi Kacang Tanah, (003). Komoditi Ubi Jalar, (008). Komoditi Kacang-kacangan lainnya, (011). Komoditi Tanaman Hias, (017). Komoditi Tanaman Biofarma, (013). Komoditi Tembakau, (014). Komoditi Tanaman Serat, (015). Komoditi Hasil Tanaman Perkebunan lainya, dan (009). Komoditi Padi-padian dan bahan makanan lainnya pada sektor
Pertanian Indonesia masih rendah dibandingkan dengan komoditi sektor pertanian lainnya.

\section{Analisis Indeks Pendapatan}

\section{Masyarakat}

Analisis indeks pendapatan masyarakat atau analisis income multiplier di Indonesia dengan menggunakan tabel Input-Output Tahun 2015, dilakukan dengan menggunakan rumus 17x17. Secara komoditi, indeks pendapatan masyarakat juga dapat dianalisis. Berdasarkan hasil analisis indeks pendapatan masyarakat secara komoditi, ketujuh belas komoditi sektor pertanian dengan hasil indeks pendapatan masyarakat. (001). Komoditi Padi sebesar 1.09 mempunyai arti bahwa untuk setiap seratus persen kenaikan output yang dihasilkan komoditi padi, total pendapatan masyarakat di Indonesia akan meningkat sebesar 1,09 persen, begitupun dengan komoditi sektor pertanian lainnya, hal ini dapat dilihat pada gambar berikut ini. 


\section{Gambar 3.}

Indeks Pendapatan Masyarakat Sektor Pertanian Indonesia
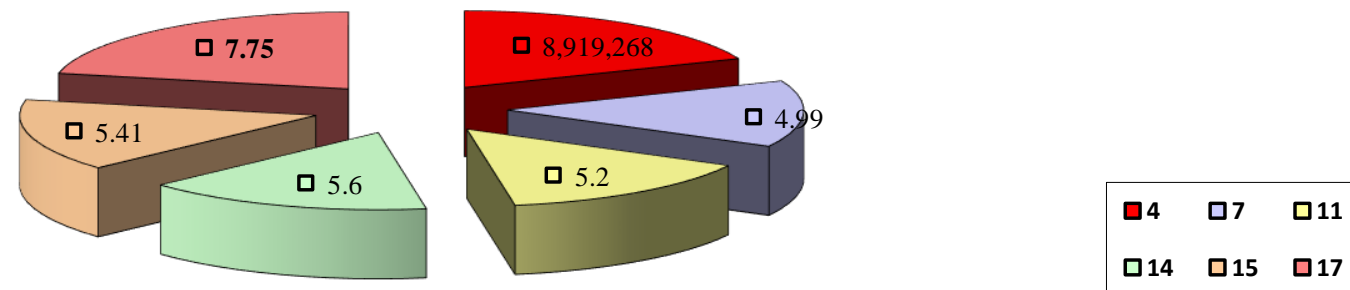

Sumber : Data diolah, 2018.

Dari perhitungan terhadap Indeks pendapatan masyarakat dirangking menjadi 6 (enam) analisis pendapatan secara komoditi yang memiliki nilai tinggi dibandingkan dengan komoditi sektor pertanian lainnya, komoditi dengan nilai indeks tertinggi adalah (017) Komoditi Tanaman Biofarma sebesar 7.75 persen, (004). Komoditi Ubi Kayu dengan nilai sebesar 6.72 persen, (014). Komoditi Tanaman Serat sebesar 5.60 persen, (015). Komoditi Hasil Perkebunan lainnya sebesar 5.41 persen, (011). Komoditi Tanaman Hias sebesar 5.20 dan (007). Komoditi Kedelai sebesar 4.99 persen, sedangkan 12 (dua belas) komoditi lainnya adalah : (002). Komoditi Jagung sebesar 2.04, (003). Komoditi Ubi Jalar sebesar 2.54, (005). Komoditi Umbi-umbian lainnya sebesar 4.53, (006). Komoditi Kacang Tanah sebesar
2.88, (008). Komoditi Kacang-kacangan lainnya sebesar 1.10, (009). Komoditi Padipadian dan bahan makanan lainnya sebesar 2.29, (010). Komoditi Sayur-sayuran sebesar 3.22, (012). Komoditi Tebu sebesar 1.02, (013). Komoditi Tembakau sebesar 1.42, (016). Komoditi Buah-buahan sebesar 1.57. Berdasarkan hasil analisis indeks pendapatan masyarakat secara komoditi, maka sektor pertanian merupakan sektor pemacu pertumbuhan pendapatan masyarakat Indonesia.

Hasil analisis indeks ketenagakerjaan dengan menggunakan tabel Input-Output Indonesia 2015 dihitung dengan menggunakan persamaan 5.4. analisis indeks ketenagakerjaan menurun menurut komoditi, hal ini tidak disajikan karena data tenaga kerja masing-masing komoditi tidak tersedia. Berdasrkan hasil analisi indeks

Program Studi Manajemen Fakultas Ekonomi Universitas Tamansiswa Padang 
Jurnal Manajemen dan Kewirausahaan, Volume 9, Nomor 3, September 2018

ISSN: $2086-5031$

E-ISSN 2615-3300

DOI 10.31317

tenaga kerja diatas, sektor-sektor perekonomian yang dikelompokkan sebagai sektor penyerap tenaga kerja di Indonesia adalah sektor Industri, sektor perdagangan dan sektor lainnya (Statistik Indonesia, 2017).

\section{SIMPULAN DAN SARAN}

\section{Simpulan}

Dengan menggunakan tabel InputOutput Indonesia tahun 2015, analisis telah dilakukan untuk melihat peran sektor Pertanian terhadap perekonomian Indonesia meliputi empat hal analisis yaitu : (1). Indeks keterkaitan kebelakang secara komoditi (backward linkage indeks), (2). Indeks keterkaitan kedepan secara komoditi (forward linkage indeks), (3). Indeks pendapatan masyarakat secara komoditi , dan (4). Indeks tenaga kerja secara sektoral. Dari hasil analisis tersebut, maka ditarik beberapa kesimpulan sebagai berikut :

1) Indeks keterkaitan kebelakangan (backward linkage indeks) dan indeks keterkaitan kedapan (forward linkage indeks) komoditi Padi, Komoditi Jagung, Komoditi Sayur-sayuran sektor pertanian menunjukkan angka besar dari satu, hal ini berarti ke tiga komoditi

2) Komoditi potensial yang harus dikembangkan dan menjadi perhatian adalah komoditi buah-buahan dengan nilai indeks keterkaitan kedepan (forward linkage indeks) sebesar 1,539903 dan nilai indeks keterkaitan kebelakang (backward linkage indeks) sebesar 0,848595, dan

3) Peran sektor pertanian terhadap peningkatan pendapatan masyarakat Indonesia menempati rangking ke tiga setelah sektor pertanianan dan sektor perdagangan, dalam sektor pertanian terdapat lima komoditi yang mempunyai nilai indeks pendapatan lebih dari satu.

\section{Saran}

Berdasarkan hasil analisis data pada bab sebelumnya, maka penulis mengemukakan beberapa saran yang membangun sebagai berikut :

1) Dari hasil perolehan Indeks keterkaitan kebelakangan (backward linkage 
Jurnal Manajemen dan Kewirausahaan, Volume 9, Nomor 3, September 2018

ISSN: $2086-5031$

E-ISSN 2615-3300

DOI 10.31317

indeks) dan indeks keterkaitan kedapan (forward linkage indeks) yang menunjukkan banyaknya komoditi sektor pertanian yang tertinggal, oleh sebab itu perlu usaha pemerintah untuk mendorong peningkatan pembangunan sektor pertanian yang lebih baik lagi, khususnya komoditi-komoditi sektor pertanian yang tertinggal,

2) Apabila sektor pertanian kembali menjadi sektor unggulan Indonesia pada saat ini, maka diharpkan pendaptan para pekerja akan meningkat dan dengan sendirinya kesejahteraan para tenaga kerja di sektor pertanian akan meningkat. Tujuan utamanya adalah untuk menekan jumlah angka kemiskinan serta angka pengangguran di Indonesia, dan

3) Bagi peneliti selanjutnya dengan menggunakan metode Input-Output Indonesia, diharapkan dapat melakukan perhitungan kesemua sektor ekonomi yang ada di Indonesia.

\section{DAFTAR PUSTAKA}

Arsyad Lincolin. 2002. Pengantar Perencanaan dan Pembangunan Ekonomi Daerah. BPFE, Yogyakarta Badan Pusat Statistik. 2017. Indonesia Dalam Angka.
Badan Pusat Statistik. 2010. Tabel Input Output Indonesia.

Badan Pusat Satistik. 2015. Indikator Pertanian Indonesia.

Boediono 2004. Pertumbuhan Ekonomi. BPFE : Yogyakarta.

Huda, Nurul. 2007. Teknik Perencanaan Pembangunan. Bung Hatta University Press. Padang

Kuncoro, Mudrajad. 2004. Metode Kuantitatif : Teori dan Aplikasi Untuk Bisnis dan Ekonomi. UPP AMP YKPN. Jakarta.

Taringan, Robinson. 2005. Ekonomi Regional Teori dan Aplikasi. PT.Bumi Aksara. Jakarta.

Sahara dan Budi P. Resosudarmo. 1996. Peran Sektor Industri Pengolahan Terhadap Perekonomian Daerah Khusus Ibukota Jakarta. Analisis I-O. Download melalui situs www.rspas.anu.edu.au.

Sjafrizal. 2008. Ekonomi Regional dan Perkotaan. Rajawali Press. Jakarta. 2014. Perencanaan Pembangunan Daerah Dalam Era Otonomi. PT. Raja Grafindo Persada. Jakarta.

Syofya. Heppi. 2009. Skripsi. Analisis Peran Sektor Industri Pengolahan Terhadap Perekonomian Kota Padang Panjang.

Todaro, Michael P. 2000. Pembangunan Ekonomi di Dunia Ketiga. 2000. Perencanaan

Pembangunan: Model dan Metode. Intermedia. Jakarta. 